\title{
木質系構造の耐火技術と設計
}

\author{
遊 佐 秀 逸*
}

1.はじめに

木質系構造の耐火技術に関しては，「木質複合建築構 造技術の開発」プロジェクト（平成 11 年度〜 15 年度, 旧建設省，国土交通省）に打いて，(1)木質複合構造の 5 階建建築物が建築可能となるような構造方法，および性 能に基づく評価法の開発，(2)木質複合構造の普及に関し て，将来の法令改正等に役立つ資料の整備，を研究目標 として活動が実施された。このうち，本稿では上記(1)を 現在の建築基準法（以下「法」と呼ぶ。）の下で実現す るための研究成果を中心に紹介する。

\section{2. 木質系構造に要求される防耐火性能}

\section{1 防火規制の概要}

木質系構造（木造建築物）には法令等による厳しい制 限が課せられてきたが，大きく 3 つの視点から考えるこ とができる。

まず第 1 に，市街地火災の防止である。大正 8 年に制 定された市街地建築物法では，防火地区制が採用され， 防火地区内の建築物は耐火構造とすることが求められ た。当時の欧米においてあ事情はほぼ同じであり，都市 部では防火区域を設定し，普通の木造建築物は禁止され ていた。

第 2 に，大規模な建築物に対する構造制限である。市 街地建築物法では, 建築物の高さについても, 而震性や 耐火性の観点から木造は厳しく制限されていた。木造の 大規模建築物が炎上すると, 単に消火が困難というだけ でなく，倒壊した場合に周辺への影響も大きい。これを 防止するために，木造の大規模建築物は禁止されている。

第 3 として, 不特定多数の人が利用する用途の建築物 など特殊建築物に対する構造制限である。昭和 7 年の白 木屋百貨店火災に扔いて多数の死者が発生したことを受 け，防火区画や避難階段の設置などが定められ，現在の 「而火建築物」の基本的な構成がつくられた。特殊建築 物は耐火建築物とすることが原則であり，木造は厳しく 制限されている。

このように従来, 木造建築物については厳しく制限が 行われてきたが，昭和 62 年の建築基準法の改正では, 木造建築物に対する制限の合理化が行われ，平成 4 年の

* ゆさ・しゅういつ/(財)ベターリビング筑波建築試験センター
改正では従来の簡易耐火建築物を包含する型で準耐火構 造，準耐火建築物が創設され，一定の耐火性能を有する 木造建築物であれば，建築できる範囲が大幅に拡大した。 さらに平成 12 年の大改正では性能規定が導入され，現 在では木質系の構造であってあ必要な性能を有する場合 には耐火構造，耐火建築物として取り扱われることが可 能となっている。

ここでは，4階建て以上の大規模な建築物を対象とし て，法に規定する耐火建築物を木質系建築物で実現する ことを中心に述べる。

法の防火関連の規定では，建物を「耐火建築物」にす れば地域，規模等の制限はない。木質系構造でこれを実 現するためには，いわ㠶ルートA（仕様規定）の方法 のうち，大臣が認定する「耐火構造」部材を適用するの が第一歩として考えられる。それは，ルートAに扔い て大臣が告示等で定める木質系の耐火構造の例示仕様が 存在しないからである。また，ルート B，ルートCで はごく一部を除いて，木質系構造に対して，汎用性を有 する手法の確立にはな打時間を要すると思われるからで ある。ここでは, 法に要求される「耐火構造」を指定性 能評価機関等での試験を伴う大臣認定部材を目差して研 究開発した結果を紹介する。検討した主要構造部材は, 柱，梁，壁，床，㧍よび階段等であり，また，本稿では 触れていないが，実際の設計ではその耐火性能を確認し ておかなくてはならない接合部，壁体内のコンセントボッ クス等についても性能確認を行った。ルート B，ルート C に関連する耐火性能検証手法および将来の法令改正に 備えた資料整備等は，本プロジェクトの報告書 を参照 されたい。

耐火建築物之して木質系建築物に要求される防火性能 は, 木質系構造に対しては構造耐火性に係わる非損傷性, 延焼防止のための遮熱性, 遮炎性等の而火性能の他に, 内装材料の制限，防火設備の性能，防火区画に関連した 区画貫通部の性能，避難安全性の確保等多岐にわたる。

而火建築物之して木質系建築物が具備すべき性能をイ メージ的に理解する例として, 木質構造の火災事例が参 考之なろう。写真-1 は木質系建築物である某学校体育 館のフラッシュオーバー時の写真である。そして写真-2 は消防活動による鎮火後の内部写真である。耐火建築物 とは，写真-1 のような状況が継続し，消防活動を行わ 


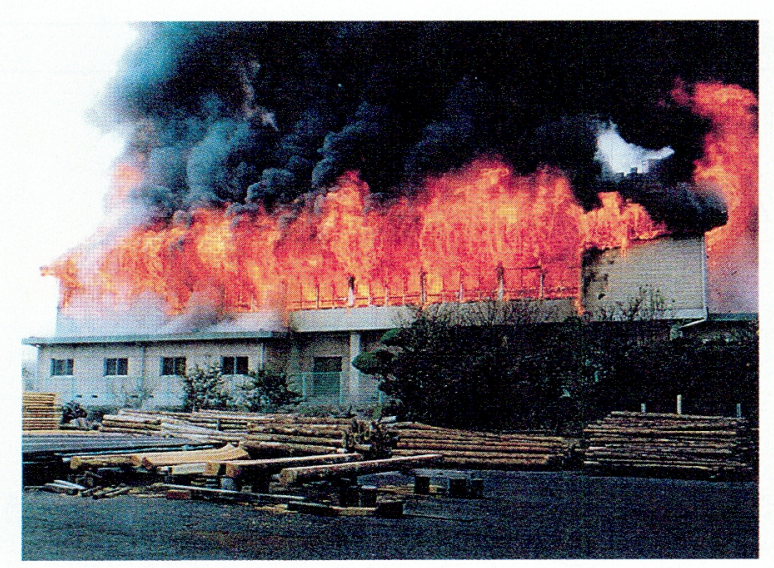

写真-1 木造体育館のフラッシュオーバー

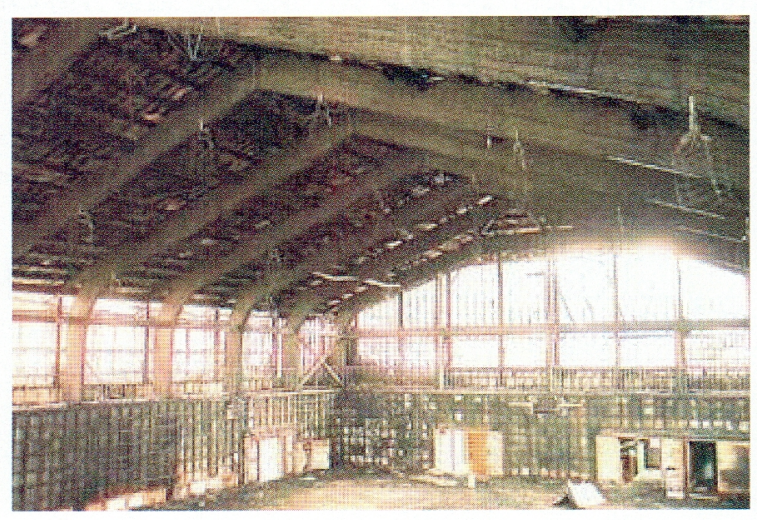

写真-2 木造体育館の火災鎮火後

表-1 要求耐火時間（耐火構造）

\begin{tabular}{|c|c|c|c|c|c|c|c|}
\hline \multirow{2}{*}{\multicolumn{3}{|c|}{ 建築物の部分 }} & \multicolumn{3}{|c|}{ 非損傷性 } & \multirow{4}{*}{$\begin{array}{l}\text { 遮熱性 } \\
1 \text { 時間 }\end{array}$} & \multirow{4}{*}{ 遮炎性 } \\
\hline & & & \multirow{2}{*}{$\begin{array}{c}\text { 最上階から } \\
4 \text { 階以内 } \\
1 \text { 時間 } \\
\end{array}$} & \multirow{2}{*}{$\begin{array}{c}\text { 最上階から } \\
5 \sim 14 \text { 階 } \\
2 \text { 時間 } \\
\end{array}$} & \multirow{2}{*}{$\begin{array}{c}\text { 最上階から } \\
15 \text { 階以上 } \\
2 \text { 時間 } \\
\end{array}$} & & \\
\hline \multirow{4}{*}{ 壁 } & \multirow{2}{*}{ 間仕切壁 } & 耐力壁 & & & & & \\
\hline & & 非耐力壁 & \multicolumn{3}{|c|}{-} & & \\
\hline & \multirow[b]{2}{*}{ 外壁 } & 耐力壁 & 1 時間 & 2 時間 & 2 時間 & 1 時間 & 1 時間 \\
\hline & & $\begin{array}{l}\text { 非耐力壁 } \\
\text { (延焼のお抢それの } \\
\text { ある部分以外) }\end{array}$ & \multicolumn{3}{|c|}{ - } & $\begin{array}{c}1 \text { 時間 } \\
\text { (30 分間) }\end{array}$ & $\begin{array}{c}1 \text { 時間 } \\
\text { (30 分間) }\end{array}$ \\
\hline \multicolumn{3}{|r|}{ 柱 } & 1 時間 & 2 時間 & 3 時間 & - & - \\
\hline \multicolumn{3}{|c|}{ 床 } & 1 時間 & 2 時間 & 2 時間 & 1 時間 & - \\
\hline \multicolumn{3}{|c|}{ はり } & 1 時間 & 2 時間 & 3 時間 & - & - \\
\hline \multicolumn{3}{|c|}{ 屋 根 } & \multicolumn{3}{|c|}{30 分間 } & - & 30 分間 \\
\hline \multicolumn{3}{|c|}{ 階 段 } & \multicolumn{3}{|c|}{30 分間 } & - & - \\
\hline
\end{tabular}

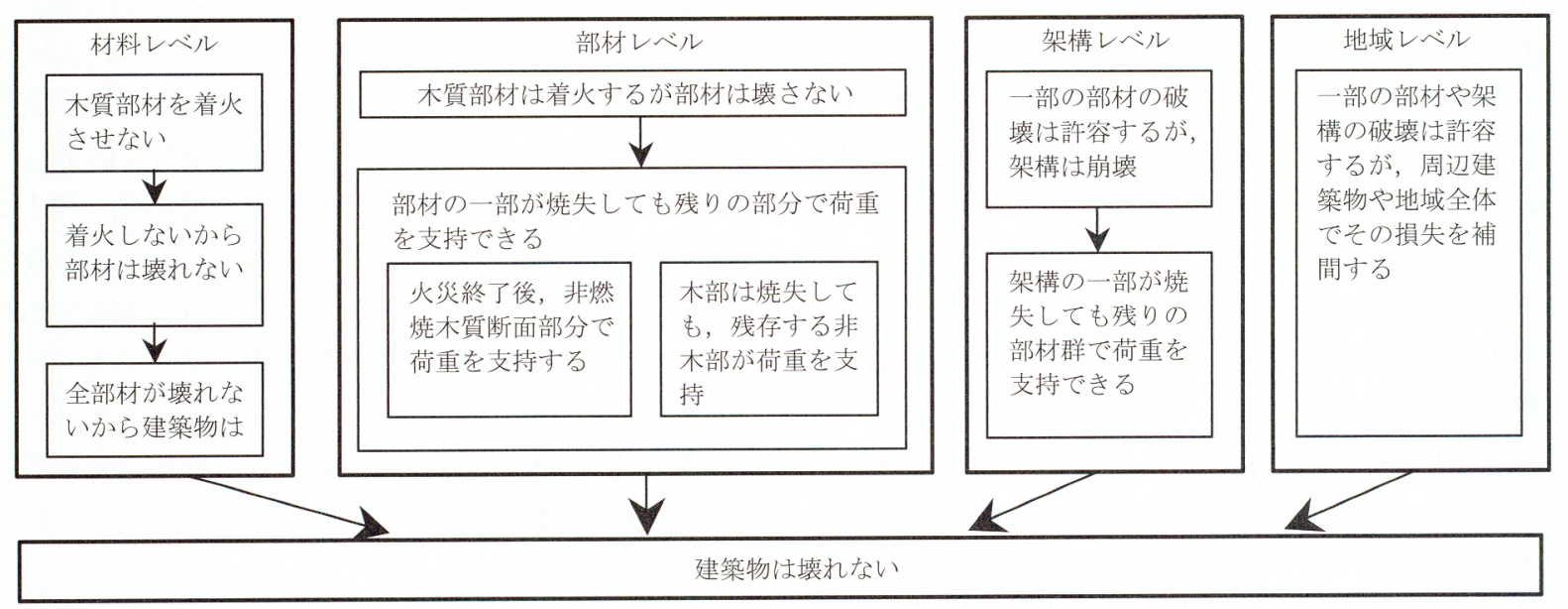

図-1＼cjkstart建築物の耐火性能評価の概念

ないで内部の可燃物が燃え尽きても写真-2のように柱, 梁, 壁等の主要構造部が荷重を支え続け，建物が崩壊せ ずに建ち続ける建築物である。すなわち，ある一定時間 経過すれば建物の崩壊を許容する準耐火建築物上根本的 に異なる点がここにあり，準耐火構造で一般的な「燃え 代設計」は適用できず「燃え止まり設計」と屯言うべき 設計手法を開発する必要がある。耐火建築物を構成する 主要構造部（法では防火規制に適用される用語であり， 構造規制に用いられる「構造上主要な部分」とは異な
る。）の部材に要求される耐火時間は表-1のように整理 される。

前述のプロジェクトにおける耐火性能評価の概念整理 の過程を踏まえて, 図-1に示すような考え方が提案さ れている ${ }^{2)}$ 。現在の法の下での耐火建築物の適合確認の 方法を図-2に示す。

本稿では, 主要構造部について, 図中の材料レベルに おける「木質部材を着火させない」を木質構造に適用し た被覆型耐火構造，および部材レベルにおける「木質部 


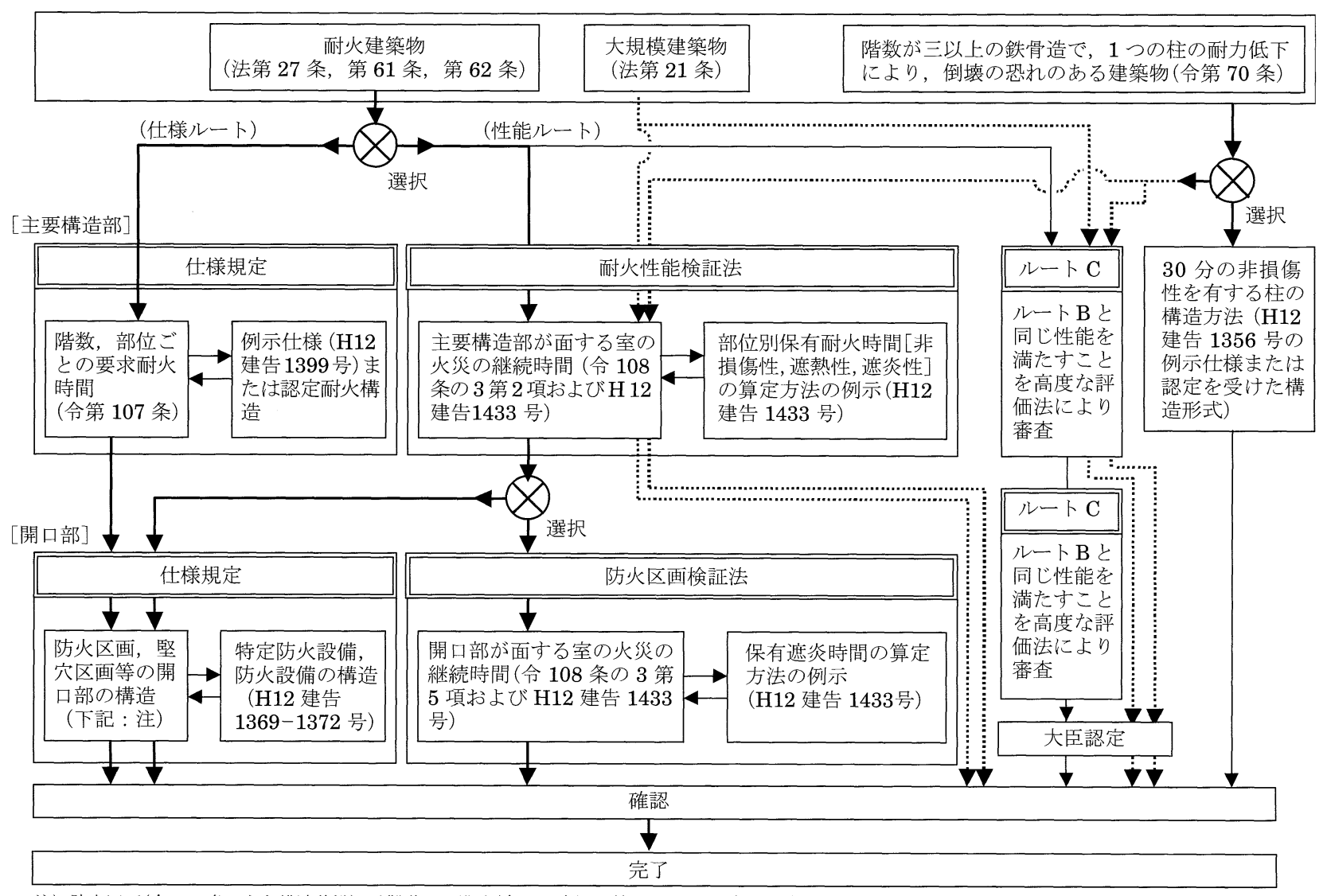

注) 防火区画(令 112 条のうち構造基準), 避難階段の構造(令 123 条),配管設備の構造(令 129 条の 2 の), 非常用の昇降機の構造(令 129 条の 13 の 3 )

図-2 耐火建築物の適合確認の方法（出典：2001 年版耐火性能検証法の解説及び計算例とその解説, 井上書店）

表-2＼cjkstart部材ハイブリッドによる耐火構造

\begin{tabular}{|c|c|c|c|}
\hline 構造概要 & 実現した構造方法 & 耐火性能試験で必要とされる性能 & 性能の説明等 \\
\hline \multirow[t]{2}{*}{$\begin{array}{l}\text { 既存の耐火構造を基とし } \\
\text { た木質系材料による被覆 }\end{array}$} & \multirow[t]{2}{*}{ 鉄骨樍造十木被覆 } & $\begin{array}{l}\text { 被覆材の燃え止り（燃焼・熱分解等の停 } \\
\text { 止）による非損㑑性の確保 }\end{array}$ & $\begin{array}{l}\text { 鉄骨温度が崩壊温度まで上昇せず, 非損傷 } \\
\text { 性等が確保される。当面柱, 梁等に適用 }\end{array}$ \\
\hline & & $\begin{array}{l}\text { 被覆材が燃え尽きても鉄骨温度が高温と } \\
\text { ならないことによる非損傷性の確保 }\end{array}$ & 同上 \\
\hline $\begin{array}{l}\text { 木質系主要構造部を被覆 } \\
\text { 材で保護した構造 }\end{array}$ & $\begin{array}{l}\text { 構造用集成材, 製材等を } \\
\text { 石こうボード等で被覆 } \\
\text { (メンブレン工法等) }\end{array}$ & $\begin{array}{l}\text { 主要構造部が炭化しないことによる非損 } \\
\text { 傷性の確保 }\end{array}$ & $\begin{array}{l}\text { 将来は, ある一定の範囲内での炭化が許容 } \\
\text { されることああり得る。当面, 壁, 床, 屋 } \\
\text { 根, 階段等に適用 }\end{array}$ \\
\hline
\end{tabular}

材は着火するが部材は壊さない」を既存の耐火構造であ る鉄骨構造に適用した「燃え止まり型」耐火構造を紹介 する。

\section{2 木質系構造部材の試験方法および試験結果}

木質系構造を実際の耐火建築物の主要構造部に耐火構 造として用いるためには，国際規格 ISO 834 に準拠し た実大規模の耐火性能試験による性能確認が必要となる。 これは, 準耐火構造における要件, すなわち，ある規定 の時間 (45 分, 60 分等) 以上に, 非損傷性, 遮熱性お よび遮炎性を満足するということではなく，法第 2 条， 耐火構造の耐火性能に記述されているように，「通常の 火災が終了するまでの間，当該火災による建築物の倒壊 および延焼を防止するために当該建築物の部分に必要々 される性能」である。これを試験方法で置き換えると， 加熱終了後も（現在の目安として，加熱時間 $\times 3$ 倍の時 間以上）当該性能を保持するということになる。すなわ
ち, 試験方法においても, 準耐火性能 1 時間（木造三階 建て共同住宅等で要求される最も長い準耐火性能）之耐 火性能 1 時間とは，まったく異質のものであるというこ とを認識する必要がある。

これまでに明らかにされた部材ハイブリッドによる耐 火構造の実現方法の概要を整理すると，表-2のように なる。構造概要の既存の耐火構造を基とした木質系材料 による被覆は, 本プロジェクトで精力的に開発を進めた もので, 鉄骨構造十木被覆の構造方法により上述の耐火 性能試験方法を適用して屯, 被覆材の燃え止り（燃焼・ 熱分解等の停止）により非損傷性が確保されるものであ る。柱および梁部材において, 鋼材の形状, 断面寸法, 被覆材の樹種, 被覆厚さ等を検討した結果, $\mathrm{H}$ 形鋼, 十字形鋼, 角鋼, フラットバー等の断面, ベイマッおよ びカラマッ集成材の 5〜8 cm 厚被覆で燃え止まり性状 が現在までに確認されている。燃え尽き型では長さ $1 \mathrm{~m}$ 


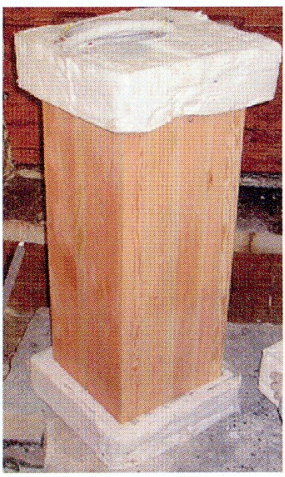

(a) 試験前

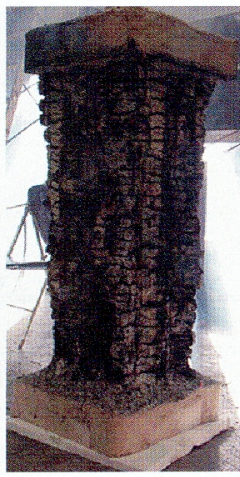

(b) 試験後（燃元 止った状況)

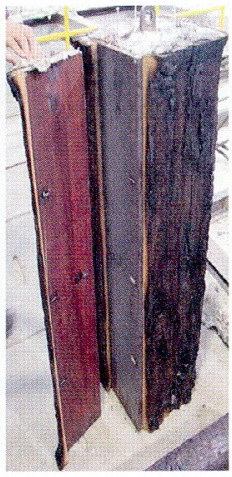

(c) 試験後（試験 体の内部断面）
写真-3 モデル柱の試験前と試験後

のモデル部材でスギ集成材被覆による 1 時間而火性能が， 実大部材では無機質系材料との組み合わせによる 2 時間 耐火性能が確認されている。燃え止まり型柱の試験前, 試験後の例を写真-3 に示す。この時の最高鋼材温度は 約 $110^{\circ} \mathrm{C}$ であり，十分な非損傷性を有している。木質 系主要構造部を被覆材で保護した構造方法では，木質系 構造部材を構造用集成材, 製材等を石こうボード等で被

\section{表-3＼cjkstart柱部材試験体仕様}

\begin{tabular}{|c|c|c|c|}
\hline \multirow{2}{*}{ No. } & \multicolumn{2}{|r|}{ 仕様 } & \multirow{2}{*}{$\begin{array}{l}\text { 加熱 } \\
\text { 時間 }\end{array}$} \\
\hline & 芯材断面 & 被覆材 & \\
\hline No.1 & $\begin{array}{c}\mathrm{H} \text { 形鋼 } \\
250 \times 250 \times 9 / 14\end{array}$ & カラマツ集成材 60 mm & \multirow{2}{*}{$\begin{array}{c}1 \text { 時間 } \\
\text { 加熱 }\end{array}$} \\
\hline No.2 & $\begin{array}{l}\text { スギ集成材 } \\
300 \times 300\end{array}$ & $\begin{array}{l}\text { 強化石こうボード }(15 \mathrm{~mm})+ \\
\text { 強化石こうボード }(12.5 \mathrm{~mm}) \times 2\end{array}$ & \\
\hline No.3 & $\begin{array}{c}\text { H 形鋼 } \\
250 \times 250 \times 9 / 14\end{array}$ & $\begin{array}{l}\text { ウェブ：不燃資材 +発泡黒鉛シート } \\
1.5 \mathrm{~mm} \times 2+\text { カラマッ集成材 } 60 \mathrm{~mm}\end{array}$ & $\begin{array}{c}2 \text { 時間 } \\
\text { 加熱 }\end{array}$ \\
\hline
\end{tabular}

表-4 梁部材試験体仕様

\begin{tabular}{|c|c|c|c|}
\hline \multirow[b]{2}{*}{ No. } & \multicolumn{3}{|c|}{ 仕 様 } \\
\hline & 芯材断面 & 被 覆 材 & $\begin{array}{c}\text { 試験体長さ } \\
(\mathrm{m})\end{array}$ \\
\hline No.1 & $\begin{array}{c}\mathrm{H} \text { 形鋼 } \\
400 \times 200 \times 8 / 13\end{array}$ & カラマツ集成材 60 mm & 6.0 \\
\hline No.2 & $\begin{array}{c}\mathrm{H} \text { 形鋼 } \\
150 \times 75 \times 5 / 7\end{array}$ & ベイマツ集成材 60 mm & $5.5(4.5)^{*}$ \\
\hline No.3 & $\begin{array}{c}\mathrm{H} \text { 形鋼 } \\
150 \times 75 \times 5 / 7\end{array}$ & カラマツ集成材 60 mm & $5.5(4.5)^{*}$ \\
\hline No.4 & $\begin{array}{l}\text { スギ集成材 } \\
400 \times 200\end{array}$ & $\begin{array}{l}\text { 強化石こうボード }(12.5 \mathrm{~mm}) \\
\times 3+\text { 合板 }(2.5 \mathrm{~mm})\end{array}$ & 6.0 \\
\hline
\end{tabular}
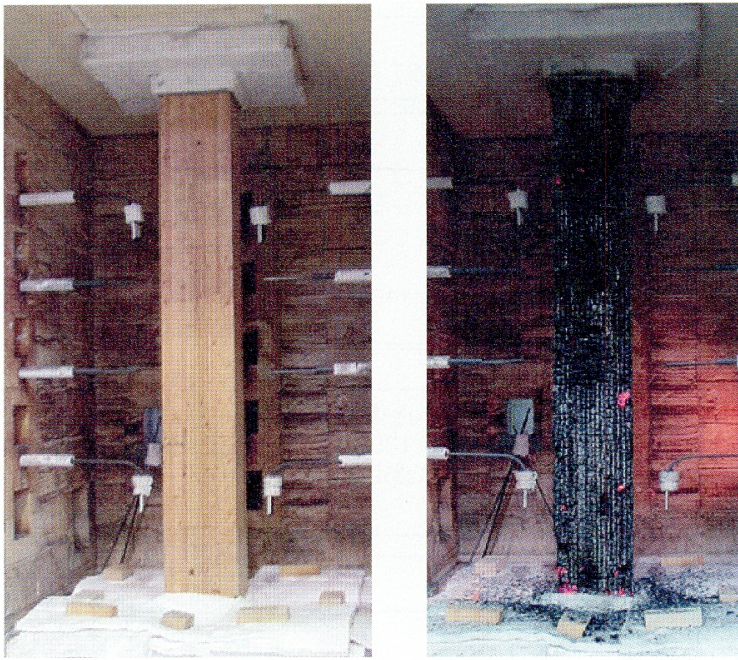

写真-4＼cjkstart柱部材試験体の状況

覆した仕様で主要構造部が炭化しないことによる非損傷 性が確保されており，これには準耐火構造で一般的なメ ンブレン工法が含まれる。以下に各々の構造で得られた 成果の一例を紹介する。

\section{3 柱および梁部材}

柱部材および梁部材の仕様をそれぞれ，表-3および 表-4 に示す。

柱部材の試験結果を表-5に示す。また，部材試験体 の状況を写真-4に示す。柱部材の試験における鋼材温 度の最高值は加熱終了後の 370 分時に $162^{\circ} \mathrm{C}$, 平均は炉 内放置中の 154 分時に $128^{\circ} \mathrm{C}$ であったので, 載荷加熱 試験を実施した場合の非損傷性（荷重支持能力）の性能 確認が，鋼材温度で裏付けられている。炉内酸素濃度測 定結果では，試験開始後 10 分時までに急減し，約 $2 \%$ となった後，15 分時に約 5\%となった。加熱終了後の 空気供給により急激に回復するものの，気中の約 $21 \%$ となるのは，180 分時以降であった。加熱停止後もしば らくの間炉内で集成材の燃焼・熱分解が進むのでこの程 度の回復遅れが生ずる。試験体 No.1の鋼材温度は, 最 高抢上び平均ともに $200^{\circ} \mathrm{C}$ 以下であり，木材を内部か ら燃焼させる温度までには至っておらず，最大軸方向収 縮変位量, 収縮速度等を勘案すると, 本実験の仕様は, 耐火構造としての性能を満足しているものと考えられる。 梁部材の実験結果を表-6に示す。燃え止まり型の大 断面である試験体 No.1 の鋼材温度の最高值は加熱終了

表-5 柱部材試験結果

\begin{tabular}{|c|c|c|c|c|c|c|c|c|}
\hline 試験体No. & $\begin{array}{l}\text { 加熱時間 } \\
\text { (分) }\end{array}$ & \multicolumn{2}{|c|}{$\begin{array}{c}\text { 鋼材または集成材表面最高温度 } \\
\left({ }^{\circ} \mathrm{C}\right)\end{array}$} & \multicolumn{2}{|c|}{$\begin{array}{c}\text { 同最大平均温度 } \\
\left({ }^{\circ} \mathrm{C}\right)\end{array}$} & $\begin{array}{c}\text { 試験荷重 } \\
(\mathrm{kN})\end{array}$ & $\begin{array}{l}\text { 最大伸び } \\
\text { (mm) }\end{array}$ & $\begin{array}{c}\text { 最大軸方向収縮速度 } \\
(\mathrm{mm} / \text { 分 })\end{array}$ \\
\hline No.1 & 60 & \multicolumn{2}{|c|}{162 (430 分) } & \multicolumn{2}{|c|}{ 128（154 分） } & 1221 & 3.0 & 0.1 以下 \\
\hline \multirow[b]{2}{*}{ No.2 } & \multirow[b]{2}{*}{60} & 辺部 & 角部 & 辺部 & 角部 & \multirow[b]{2}{*}{510} & \multirow[b]{2}{*}{ 3. 6} & \multirow[b]{2}{*}{0.1 以下 } \\
\hline & & 133.9 (142 分) & 230.6 (115 分) & 121.3 (157 分) & 198.0 (126.5 分) & & & \\
\hline No.3 & 120 & \multicolumn{2}{|c|}{354.4 (139 分) } & \multicolumn{2}{|c|}{309.3 (144 分) } & 1221 & 5.5 & 0.1 以下 \\
\hline
\end{tabular}

（）.内の時間は試験関始後からの時間を示す。 

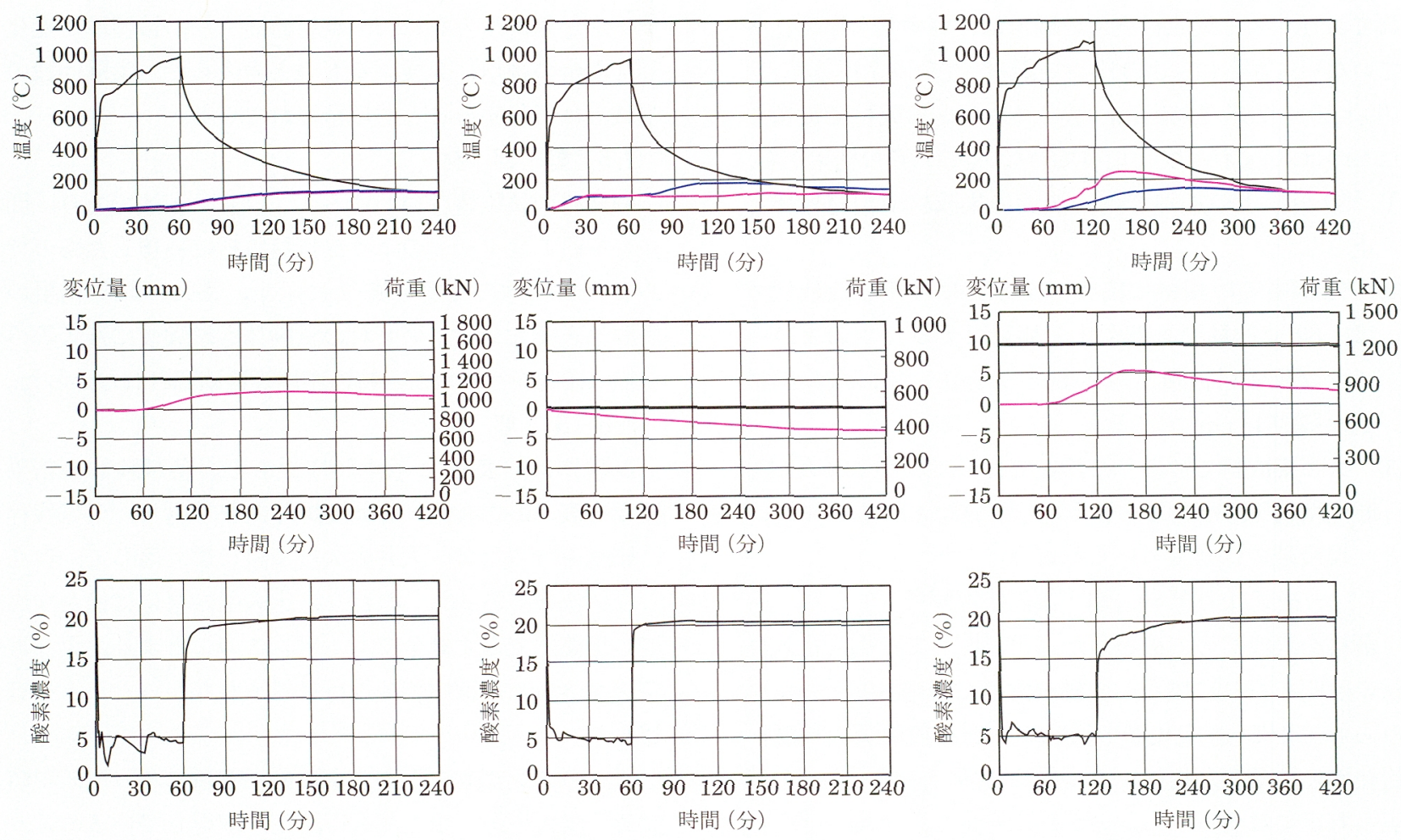

試験体 No.1

試験体 No.2

試験体 No.3

図-3 柱部材試験結果

\section{表-6 梁実験結果}

\begin{tabular}{|c|c|c|c|c|c|c|c|c|c|}
\hline 試験体 No. & $\begin{array}{l}\text { 加熱時間 } \\
\text { (分) }\end{array}$ & \multicolumn{2}{|c|}{$\begin{array}{c}\text { 鋼材または集成材の表面温度 } \\
\left({ }^{\circ} \mathrm{C}\right)\end{array}$} & \multicolumn{2}{|c|}{$\begin{array}{c}\text { 同最大平均温度 } \\
\left({ }^{\circ} \mathrm{C}\right)\end{array}$} & $\begin{array}{c}\text { 試験荷重 } \\
(\mathrm{kN})\end{array}$ & $\begin{array}{c}\text { 最大たわみ } \\
(\mathrm{mm})\end{array}$ & $\begin{array}{c}\text { 最大たわみ速度 } \\
(\mathrm{mm} / \text { 分 })\end{array}$ & $\begin{array}{c}\text { 初期たわみ } \\
\quad(\mathrm{mm})\end{array}$ \\
\hline No.1 & 60 & \multicolumn{2}{|c|}{116.7 (243 分) } & \multicolumn{2}{|c|}{114.5 (267 分) } & 202.7 & 7.4 & 1.2 & 7.0 \\
\hline No.2 & 60 & \multicolumn{2}{|c|}{153 (211.5 分) } & \multicolumn{2}{|c|}{151 (211.5 分) } & 16 & 25 & 3.2 & - \\
\hline No.3 & 60 & \multicolumn{2}{|c|}{140 (192 分) } & \multicolumn{2}{|c|}{138 (191分) } & 16 & 20 & 2.4 & - \\
\hline \multirow[b]{2}{*}{ No.4 } & \multirow[b]{2}{*}{60} & 辺部 & 角部 & 辺部 & 角部 & \multirow[b]{2}{*}{43.7} & \multirow[b]{2}{*}{27.2} & \multirow[b]{2}{*}{1.8} & \multirow[b]{2}{*}{8.4} \\
\hline & & $\begin{array}{l}170.9 \\
(145 \text { 分) }\end{array}$ & $\begin{array}{c}255 \\
(128.5)\end{array}$ & $\begin{array}{c}157.6 \\
(156.5 \text { 分) }\end{array}$ & $\begin{array}{c}252.5 \\
(132 \text { 分) }\end{array}$ & & & & \\
\hline
\end{tabular}

（）内の時間は試験開始後からの時間を示す。

後の放置中にピークに達し, 断面 B F F の下フランジ部 で 240 分時に $117^{\circ} \mathrm{C}$ であり, 平均は炻内放置中の 267 分時に $115^{\circ} \mathrm{C}$ であった。当該部材の変形性状は, 加熱 終了直後加急速に增大し, 最大 $7 \mathrm{~mm}$ に達した後, 徐々に減少した。燃え止り型の小断面試験体 No.2 抢上

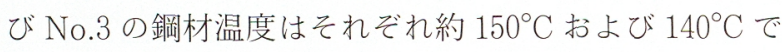
いずれも 240 分以前である。梁は 3 面加熱であり，柱の 4 面之比較すると熱の侵入が少ないが，大断面に比べて 小断面では約 $20^{\circ} \mathrm{C}$ 鋼材温度が高くなっている。

被覆型試験体については, 詳細は省略するが, 要する に木材が炭化しない上うな被覆, 例えば石こうボード等 の被覆材の積層仕様, 厚さ仕様を見いだしたということ である。施工にあたっては，ボードを取り付ける釗，ネ ジ類は, 最外層を避けて中間層に止兴る゙さきであろう。

\section{4 柱および梁部材における燃え止り性状の検討}

木質系構造で耐火構造を実現する手法として前述のプ ロジェクトに扔いて初めて本格的に実験的に検討された 「燃え止り性状」について概要を述べる。
（1）燃え止り性状に関して

近年の燃え止りに関するこれまでの実験的研究結果に よると，山口らががイマッのエンジニアリングウッド (断面寸法 $550 \times 550 \mathrm{~mm}, 60$ 分または 120 分加熱）や ケヤキ（Ф $300 \mathrm{~mm}, 60$ 分加熱） ヒバ（150×150 mm, 45 分加熱）の製材で，その性状を調査した結果では， すべての場合において，加熱終了後 15 30 分程度で試 験体表面の残炎は一旦消滅するものの, 炉を開放した時 点で試験体表面から炎が立ち上がる再燃現象が見られて いる。また，須藤ら5のカラマッ集成材，スギ製材等に 関しての燃え止りに関する研究では, 15 分加熱ではす べて燃元止っており，20 分加熱では，スギを除いて燃 え止りが観察されている。30 分加熱では，いずれも燃 え止らなかった。

前述のプロジェクト研究では, H 形鋼をカラマッ被 覆した場合, H $250 \times 250 \times 9 / 14$ で 60 分加熱で然え止まっ ている。カラマッ, ベイマッに関しては, これまで $\mathrm{H}$ $150 \times 75 \times 5 / 7$, H $300 \times 300 \times 10 / 15$ で燃え止りが確認さ 
れており，スギ集成材被覆の場合は，いずれも燃え止っ ていない。さらに，より小さい鋼材 $(\mathrm{T} 75 \times 75 \times 5 / 7, \mathrm{H}$ $100 \times 50 \times 4 / 6 ）$ を $60 \mathrm{~mm}$ 厚のカラマッ集成材で被覆し たあのは,いずれも燃え止っていない。これらの結果から， (1) 30 分以上の加熱では，無垢の集成材や製材は燃え 止らない。

(2) $\mathrm{H}$ 型鋼等の鋼材に集成材を密実に被覆した仕様で は, 60 分加熱でも燃え止る樹種はカラマッおよびべ イマッ集成材被覆（厚さ50 80 mm）で，最小鋼材 断面積約 $18 \mathrm{~cm}^{2}$ である。

(3) スギ集成材で被覆した仕様では，これまで最大鋼材 断面積約 $118 \mathrm{~cm}^{2}$ でも燃え止りが確認されていない。 と，現段階では結論づけられよう。

（2）燃え止り部材に関する熱伝導解析

鋼材を集成材等で被覆した部材に関して，燃え止り性 状の解明ならびに燃え尽き材も含めた鋼材温度予測が試 みられている ${ }^{6}$ 。炭化層の形成およびその亀裂の程度, 炭化層の脱落等が樹種により異なるので, 燃え止りの確 実な判定には至っていないが，燃え止り，燃え尽きの各 性状における熱伝導等を基にした鋼材温度上昇予測はあ る程度可能となっている。したがって，ある樹種の基礎
データが確かめられれば, 鋼材断面寸法, 被覆厚が变化 した場合の適用に発展するものと考えられ, 実験回数の 削減等に寄与することが期待されている。

\section{5 壁 部 材}

壁部材の試験体はいわゆるメンブレン工法であり, 間 柱等を石こうボードのような無機質材で被覆したもので ある。試験体の概要を表-7に示す。また, 試験結果の 概要を表-8に示す。いずれの試験体も試験後に残火等の 有無の確認を行ったが，特に燃焼等は確認されなかった。

\section{6 床 部 材}

試験体は, 表-9 に示す仕様である。各試験体の結果 概要を表-10に示す。試験後炉外に取り出し, 火気残存 の確認を行ったが, 天井耐火被覆材は燃え落ちて, 存在 しない状態であった。ただし，床大引き材には僅かな燃 焼しか確認できず健全であった。このことより, 天井被 覆材が落ちた後は燃焼の進行は見られなかったことを確 認した。

以上のメンブレン工法および屋根部材にあって, 現時 点で「耐火構造」として大臣認定を取得しているのは, 概ね枠組壁工法 $(2 \times 4$ 工法）である。これらの詳細に ついては,「枠組壁工法による木質複合建築物設計の手

表-7 壁試験体仕様

\begin{tabular}{|c|c|c|c|c|c|}
\hline \multirow{2}{*}{ No. } & \multirow{2}{*}{ 部位 } & \multicolumn{3}{|c|}{ 仕様 } & \multirow{2}{*}{ 備考 } \\
\hline & & 加熱側被覆材 & 非加熱側被覆材 & 壁内部 & \\
\hline No.1 & 外壁 & $\begin{array}{l}\text { 硬質木片セメント板 }(25 \mathrm{~mm})+ \\
\text { 軽量気泡コンクリートパネル }(35 \mathrm{~mm})\end{array}$ & $\begin{array}{l}\text { 強化石こうボード }(21 \mathrm{~mm}) \text { 横張 }+ \\
\text { 強化石こうボード }(15 \mathrm{~mm})\end{array}$ & $\begin{array}{l}\text { グラスウール } \\
10 \mathrm{~K}(50 \mathrm{~mm})\end{array}$ & 両面合板張りパネル \\
\hline No.2 & 間仕切壁 & $\begin{array}{l}\text { 強化石こうボード }(21 \mathrm{~mm}) \text { 横張 }+ \\
\text { 強化石こうボード }(15 \mathrm{~mm})\end{array}$ & $\begin{array}{l}\text { 強化石こうボード }(21 \mathrm{~mm}) \text { 横張 }+ \\
\text { 強化石こうボード }(15 \mathrm{~mm})\end{array}$ & $\begin{array}{l}\text { グラスウール } \\
10 \mathrm{~K}(50 \mathrm{~mm})\end{array}$ & 両面合板張りパネル \\
\hline No.3 & 間仕切壁 & $\begin{array}{l}\text { 強化石こうボード }(21 \mathrm{~mm}) \text { 横張 }+ \\
\text { 強化石こうボード }(15 \mathrm{~mm})\end{array}$ & $\begin{array}{l}\text { 強化石こうボード }(21 \mathrm{~mm}) \text { 横張 }+ \\
\text { 強化石こうボード }(15 \mathrm{~mm})\end{array}$ & なし & $\begin{array}{l}\text { 片面合板張りパネル } \\
\text { 加熱側：合板なし }\end{array}$ \\
\hline
\end{tabular}

表-8 壁試験結果

\begin{tabular}{|c|c|c|c|c|c|c|c|c|c|c|c|}
\hline \multirow{2}{*}{ 試験体 } & \multirow{2}{*}{$\begin{array}{c}\text { 載荷荷重 } \\
(\mathrm{tf}) \\
(\mathrm{kN})\end{array}$} & \multirow{2}{*}{$\begin{array}{c}\text { 初期温度 } \\
\left({ }^{\circ} \mathrm{C}\right)\end{array}$} & \multirow{2}{*}{$\begin{array}{l}\text { 加熱時間 } \\
\text { (分) }\end{array}$} & \multirow{2}{*}{$\begin{array}{l}\text { 試験時間 } \\
\text { (上段) } \\
\text { 放置時間 } \\
\text { (下段) } \\
\text { (分) }\end{array}$} & \multirow{2}{*}{$\begin{array}{l}\text { 軸方向 } \\
\text { 最大 } \\
\text { 変位量 } \\
(\mathrm{mm})\end{array}$} & \multirow{2}{*}{$\begin{array}{c}\text { 面外方向 } \\
\text { 最大 } \\
\text { 変位量 } \\
(\mathrm{mm})\end{array}$} & \multirow{2}{*}{$\begin{array}{c}\text { 軸方向 } \\
\text { 最大 } \\
\text { 変位速度 } \\
(\mathrm{mm} / \text { 分) }\end{array}$} & \multicolumn{2}{|c|}{$\begin{array}{c}\text { 試験体裏面下段は } \\
\text { 到達時間（分） }\end{array}$} & \multirow{2}{*}{$\begin{array}{c}\text { 試験終了 } \\
\text { 時間 } \\
\text { (分) }\end{array}$} & \multirow{2}{*}{$\begin{array}{c}\text { 試験終了時の } \\
\text { 状況現象等 } \\
\text { その他 }\end{array}$} \\
\hline & & & & & & & & $\begin{array}{l}\text { 最高温度 } \\
\text { （分） }\end{array}$ & $\begin{array}{c}\text { 平均温度 } \\
\text { (分) }\end{array}$ & & \\
\hline \multirow{2}{*}{ No.1 } & \multirow{2}{*}{$\begin{array}{r}8.1 \\
79.5\end{array}$} & \multirow{2}{*}{13} & \multirow{2}{*}{60} & \multirow{2}{*}{$\begin{array}{l}240 \\
180\end{array}$} & \multirow{2}{*}{3.1} & \multirow{2}{*}{13.4} & \multirow{2}{*}{0.20} & $36^{\circ} \mathrm{C}$ & $33^{\circ} \mathrm{C}$ & \multirow{2}{*}{240} & \multirow{2}{*}{$\begin{array}{l}\text { 壁内軸組： } \\
\text { なし }\end{array}$} \\
\hline & & & & & & & & 169.0 & 178.0 & & \\
\hline \multirow{2}{*}{ No.2 } & \multirow{2}{*}{$\begin{array}{r}8.1 \\
79.5\end{array}$} & \multirow{2}{*}{10} & \multirow{2}{*}{60} & \multirow{2}{*}{$\begin{array}{l}240 \\
180\end{array}$} & \multirow{2}{*}{1.7} & \multirow{2}{*}{-15.5} & \multirow{2}{*}{0.20} & $34^{\circ} \mathrm{C}$ & $32^{\circ} \mathrm{C}$ & \multirow{2}{*}{240} & \multirow{2}{*}{$\begin{array}{l}\text { 壁内軸組： } \\
\text { 燃焼なし }\end{array}$} \\
\hline & & & & & & & & 153.0 & 177.0 & & \\
\hline \multirow{2}{*}{ No.3 } & \multirow{2}{*}{$\begin{array}{r}7.2 \\
70.6\end{array}$} & \multirow{2}{*}{13} & \multirow{2}{*}{60} & \multirow{2}{*}{$\begin{array}{l}240 \\
180\end{array}$} & \multirow{2}{*}{5.1} & \multirow{2}{*}{12.6} & \multirow{2}{*}{0.30} & $51^{\circ} \mathrm{C}$ & $44^{\circ} \mathrm{C}$ & 240 & 壁内軸組： \\
\hline & & & & & & & & 76.0 & 127.0 & 240 & 燃焼なし \\
\hline
\end{tabular}

表-9 床試験体仕様

\begin{tabular}{|c|c|c|c|c|c|}
\hline \multirow{2}{*}{ No. } & \multirow{2}{*}{ 工法 } & \multicolumn{3}{|c|}{ 仕様 } & \multirow{2}{*}{ 備考 } \\
\hline & & 加熱側被覆材 & 非加熱側被覆材 & 天井内部 & \\
\hline No.1 & $\begin{array}{l}\text { 木質 } \\
\text { プレハブ }\end{array}$ & $\begin{array}{l}\text { 強化石こうボード }(21 \mathrm{~mm}) \text { 下地+ } \\
\text { 強化石こうボード }(15 \mathrm{~mm})\end{array}$ & $\begin{array}{l}\text { 硬質木片セメント板 }(18 \mathrm{~mm}) \text { 下地 }+ \\
\text { 構造用合板 }(12 \mathrm{~mm})\end{array}$ & $\begin{array}{l}\text { ロックウール } \\
40 \mathrm{~K}(55 \mathrm{~mm})\end{array}$ & $\begin{array}{l}\text { 木製野縁, 格子組 } \\
\text { 吊り天井, 吊梁 : } 39 \mathrm{~mm} \times 172 \mathrm{~mm} 1 \text { 本 } \\
\text { 床パネルと吊梁との隙間 : } 10 \mathrm{~m}\end{array}$ \\
\hline No.2 & $\begin{array}{l}\text { 本質 } \\
\text { プレハブ }\end{array}$ & $\begin{array}{l}\text { 強化石こうボード }(21 \mathrm{~mm}) \text { 下地 }+ \\
\text { 強化石こうボード }(15 \mathrm{~mm})\end{array}$ & $\begin{array}{l}\text { 硬質本片セメント板 }(18 \mathrm{~mm}) \text { 下地+ } \\
\text { 構造用合板 }(12 \mathrm{~mm})\end{array}$ & $\begin{array}{l}\text { ロックウール } \\
40 \mathrm{~K}(55 \mathrm{~mm})\end{array}$ & $\begin{array}{l}\text { 木製野縁, 格子組 } \\
\text { 吊り天井, 吊梁 : } 39 \mathrm{~mm} \times 172 \mathrm{~mm} 2 \text { 本 } \\
\text { 床パネルと吊梁との隙間 : } 40 \mathrm{~mm}\end{array}$ \\
\hline
\end{tabular}


表-10 床試験結果

\begin{tabular}{|c|c|c|c|c|c|c|c|c|c|}
\hline \multirow{2}{*}{ 試験体 } & \multirow{2}{*}{$\begin{array}{l}\text { 載荷荷重 } \\
\text { (tf) } \\
(\mathrm{kN})\end{array}$} & \multirow{2}{*}{$\begin{array}{c}\text { 初期温度 } \\
\left({ }^{\circ} \mathrm{C}\right)\end{array}$} & \multirow{2}{*}{$\begin{array}{c}\text { 加熱時間 } \\
\text { （分） }\end{array}$} & \multirow{2}{*}{$\begin{array}{c}\text { 座屈時間（上段） } \\
\text { 放置時間（下段） } \\
\text { (分) }\end{array}$} & \multirow{2}{*}{$\begin{array}{l}\text { 最大たわみ量 } \\
\text { （mm） } \\
\text { 下段は到達時間 } \\
\quad \text { (分) }\end{array}$} & \multicolumn{2}{|c|}{ 試験体裏面 } & \multirow{2}{*}{$\begin{array}{l}\text { 試験終了時間 } \\
\text { (分) }\end{array}$} & \multirow{2}{*}{$\begin{array}{c}\text { 試験終了時の } \\
\text { 状況現象等 } \\
\text { その他 }\end{array}$} \\
\hline & & & & & & 最高 (分) & 平均 (分) & & \\
\hline \multirow{2}{*}{ No.1 } & \multirow{2}{*}{$\begin{array}{c}6.1 \\
59.0\end{array}$} & \multirow{2}{*}{13} & \multirow{2}{*}{60} & なし & \multirow{2}{*}{$\begin{array}{c}16.8 \\
(240.0)\end{array}$} & \multirow{2}{*}{$\begin{array}{c}47.3 \\
(240.0)\end{array}$} & \multirow{2}{*}{$\begin{array}{c}43.1 \\
(240.0) \\
\end{array}$} & \multirow{2}{*}{240} & \multirow{2}{*}{$\begin{array}{l}\text { 木製野縁 } \\
\text { 一部燃焼 }\end{array}$} \\
\hline & & & & 180 & & & & & \\
\hline \multirow{2}{*}{ No.2 } & \multirow{2}{*}{$\begin{array}{c}4.5 \\
44.2\end{array}$} & \multirow{2}{*}{11} & \multirow{2}{*}{60} & なし & \multirow{2}{*}{$\begin{array}{c}9.4 \\
(240.0)\end{array}$} & \multirow{2}{*}{$\begin{array}{c}26.9 \\
(240.0)\end{array}$} & \multirow{2}{*}{$\begin{array}{c}26.6 \\
(240.0)\end{array}$} & \multirow{2}{*}{240} & \multirow{2}{*}{$\begin{array}{l}\text { 木製野縁 } \\
\text { 一部変色 }\end{array}$} \\
\hline & & & & 180 & & & & & \\
\hline
\end{tabular}
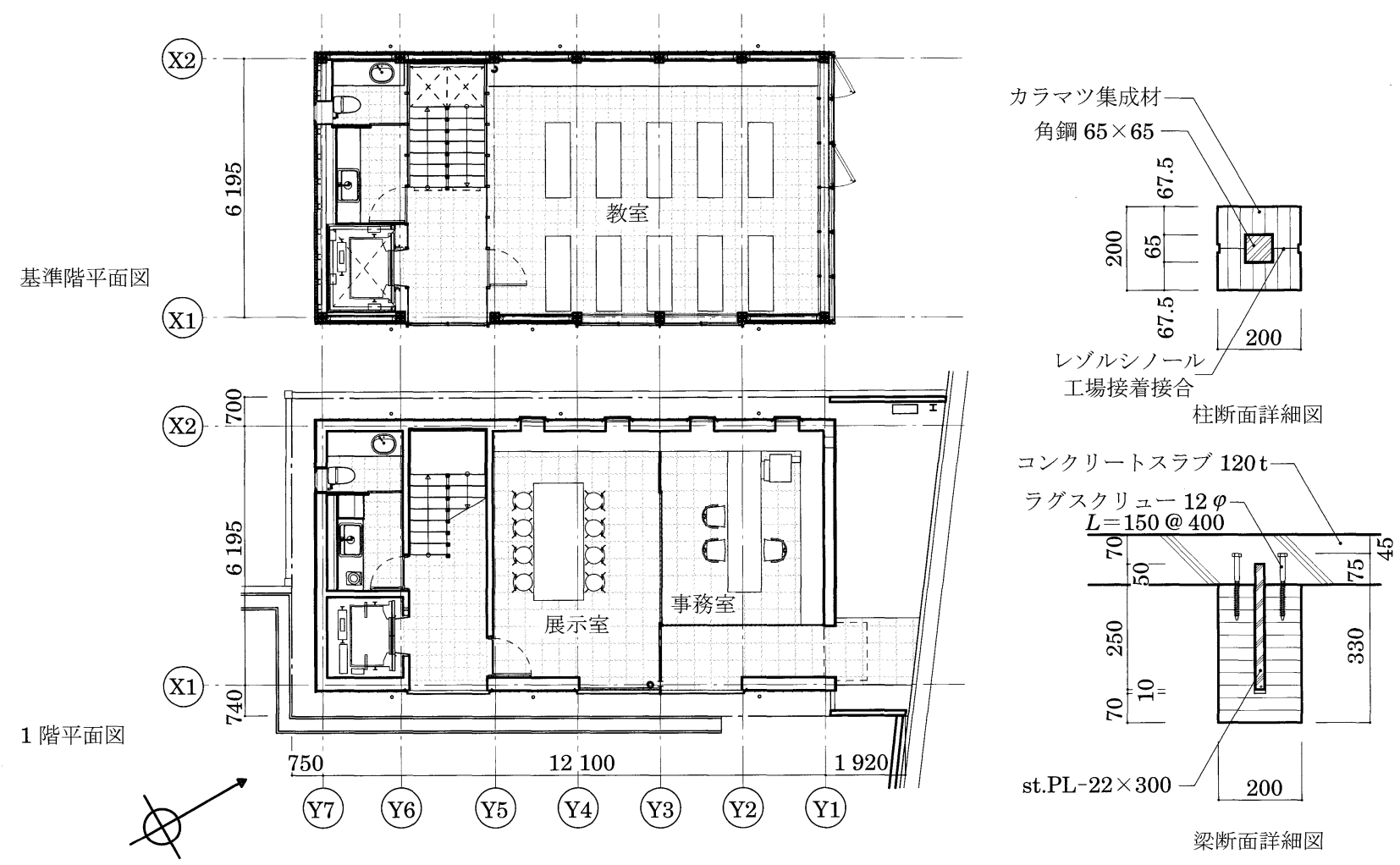

図-4 エムビル平面図

引き」, (社) 日本ッーバイフォ一建築協会発行, を参照 されたい。

\section{3. 木質系構造の耐火設計（5 階建て建築物が 可能となる構造方法）}

冒頭の目的で述べた 5 階建て建築物の防耐火に関する 要件は, 建築する地域抢よび建物の規模等に応じて構造 耐火性, 避難, 内装制限, 設備等多岐にわたるが, ここ では,ルートA での構造耐火性すなわち「耐火構造」 の実現を中心に紹介することとする。

建物の階数に対する耐火性能の要求は, 冒頭の表-1 に示したように上から 4 層の柱, 梁, 壁, 床等の建築物 の部分の要求耐火時間は 1 時間であり, 上から 5 層以上 で 14 層以内の階では 2 時間である。すなわち, 一般に 5 階建ての 1 階部分は 2 時間の耐火性能が要求され, 2〜 階は 1 時間の耐火性能が要求される（屋根および 階段等を除く)。

「木質複合建築構造技術の開発」プロジェクトでは，2 時間の耐火性能が確認されたのは, 木材を被覆した壁
(メンブレン工法), および柱の 1 仕様（いずれあ大臣認 定は未取得）であり，これらを応用すれば木質複合構造 の 5 階建て建築部物が実現できる可能性がある。ただし， 梁や床の性能確認はまだなされていない。このような状 況下において現時点で木質系構造の耐火設計を実現する 構造方法として 1 階部分がコンクリート構造, 2〜5 階 木質系構造という構造が検討され，実施設計が行われて 平成 17 年 8 月に金沢駅前に建設された（エムビル）。こ れは, 柱, 梁部を鉄骨構造としてその座屈や变形を防止 するのに木材を利用したものであり，平面図を図-4に 示す。

主要構造部は, 基本的には鉄骨ラーメン構造であるが, 耐火性能実現の方法は前述のプロジェクトで明らかにさ れた燃え止り性状を応用している。柱, 梁の断面は, 構 造設計で可能な範囲で出来るだけ小さくすることとされ， 一般的な $\mathrm{H}$ 形鋼や鋼管を用いず，木製の構造耐力を勘 案した角型中実鋼柱および平鋼梁が，検討されたのであ る。モデル部材で角鋼柱仕口部等の性能確認を経て, 柱, 梁とも載荷加熱による性能評価試験を実施して大臣認定 
を取得している。

4.おわりに

建築基準法の性能規定化により，性能を有すれば木質 系耐火構造が可能となる例を示した。ここでの方法はい わゆる仕様ルート（ルートA）と称されているあので ある。今後は性能ルート（ルート B，ルートC）におけ る木質系構造への適用，大臣認定に係る試験，評価業務 方法書に規定する試験方法, 評価方法のさらなる検討に よって, より適用範囲が拡大する屯のと考えられる。こ の種の開発で留意しておかなければならないのは, 前述 の実施設計例のように，我が国では一般に構造設計が先 行するということである。地震, 風, 雪等の荷重に対す る安全確保, さらには木質系特有のクリープ変形等を含 む耐久性をあらかじめ確認することあ必要である。これ
らの問題をクリアして適切な設計手法が確立されること が望まれる。

\section{参考文献}

1）国土交通省国土技術政策総合研究所, 独立行政法人建築研究所, 財団法人日本建築センター：木質複合建築構造技術の開発，平成 $13,14,15$ 年度報告書 防火分科会, 2002 年, 2003 年および 2004 年 3 月

2）池田憲一：高層木造建築物の火災安全設計，2004 年度日本建築 学会大会 (北海道) 防火部門研究協議会資料, pp.21 27, 日本 建築学会防火委員会, 2004 年 8 月

3）遊佐秀逸・増田秀昭ほ加：木質系構造の耐火性能に関する研究 その 1 その 21 , 日本建築学会大会学術講演梗概集 A-2, 防火, 2003 年 9 月〜 2005 年 9 月

4）山口純一・村岡 宏ほか：大断面木材の加熱実験, 平成 14 年度 日本火災学会研究発表会概要集, 2002 年 5 月

5）須藤昌照・山田 誠ほか：本質系構造部材の燃え止りに関する研 究, 日本建築学会大会学術講演梗概集，2003 年 9 月

6）原田和典・梶山幸祐ほか：木質構造部材の炭化性状に関する数值 解析, 日本建築学会近畿支部研究報告集, 第 43 号環境系, pp. $209 \sim 212,2004$ 年 6 月

$=\ll$ 圈案内 $\gg$

\section{コンクリート構造物のポストピーク挙動評価と設計への応用}

重要な構造物の設計においては，ポストピーク挙動に関する情報は必須と言っても良い。本書は，「コンクリート構造物のポ ストピーク挙動解析に関する研究委員会」(委員長：田辺忠顕 名古屋大学大学院教授） 4 年間の活動に扔いて, コンクリート 構造物のポストピーク挙動に関して活発に議論した内容, 特に, 各種コンクリート構造物のポストピーク挙動, 耐荷力とポスト ピーク挙動を予測するための最新の非線形解析手法, ポストピーク領域の設計への応用などについて, 有用な成果をとりまとめ たものである。

1. ポストピーク挙動評価の工学的意義 2. $\mathrm{RC}$ 構造物のポストピーク挙動に関する実験的検討

3. 材料レベルのポストピーク挙動とそのモデル化 4. ポストピーク領域の数值解析法

5. RC 構造物のポストピーク挙動の解析 6. 衝撃の問題に対するポストピーク解析の応用

7. ポストピーク挙動評価と設計への応用

参考文献

索引

B 5 判・277 ページ（2003 年刊行）／定価 10500 円（税込), 会員特価 9450 円（税込)／送料 390 円

-申込先：(社) 日本コンクリート工学協会「書籍販売」係

干102-0083＼cjkstart東京都千代田区麹町 1-7＼cjkstart相互半蔵門ビル 12 階／電話（03）3263-1573

〈申込方法〉郵便振替（振替口座：00120-5-99133・加入者名：社団法人日本コンクリート工学協会）にて払い込み・抒申 込み下さい。代金（書籍代・送料合計）受領次第お送りします（振替手数料は申込者にてご負担願います）。 通信欄に書籍名・冊数・当協会会員の場合は会員番号を明記して下さい。 ご依頼人闌（抢届け先）に郵便番号・住所・名称・担当者名・電話番号を必ず明記して下さい。 送料は 1 冊分の金額ですので，2冊以上お申込みの場合は，お問合せ下さい。 